\title{
Lung cancer - statistical analysis data from 2016 to 2019 in Shtip, Republic of North Macedonia
}

\author{
Jihe Zhu ${ }^{1,}$ Blagica Arsovska ${ }^{1,2,}$ Kristina Kozovska ${ }^{1,3}$ \\ ${ }^{1}$ Faculty of Medical Sciences, University Goce Delchev, Shtip, Republic of Macedonia; \\ ${ }^{2}$ Institute of Biology, Faculty of Natural Sciences and Mathematics, Skopje, Republic of Macedonia \\ ${ }^{3}$ Medicine Faculty, St. Cyril and Methodius University of Skopje, Republic of Macedonia
}

\begin{abstract}
According to the data of the World Health Organization, globally, in 2018, 18 million new cases of cancer were registered, of which 2.09 million (11.6\%) were diagnosed with lung cancer and 9.6 million deaths, of which 1.76 million (18.4) are in lung cancer. The overall standardized incidence rate by age is $25 \%$ higher in men than in women. Statistical data taken from the Center for public health - Shtip, shows that lung cancer is more common in men and more common in people aged 55-65, while in women there is no dominance of a certain age group. The total number of newly registered cases of lung cancer in Stip for 2016 is a total of 25 . In 2017 the total number is 35 of which 30 of the patients are men, most of them are aged 55 to 65 years. In 2018 the total number is 22. The total number of newly registered cases of lung cancer in Shtip for 2019 is 7 of which are all registered in men, most are aged 45 to 54 and 65 to 75 years. Due to the frequency of this type of cancer, it is important to raise the awareness in people to prevent or detect the disease early, which improves the chances for a better prognosis and a better outcome of treatment.
\end{abstract}

Keywords: lungs, cancer, statistics, Macedonia

\section{Introduction}

The lungs are the main organs of the respiratory system. The basic function of the lungs is respiratory, which consists in the transport of atmospheric oxygen in the blood and elimination of carbon dioxide from the blood into the atmosphere. Lung cancer with its frequency and high mortality, as well as the series of etiological unknowns, is a huge challenge for the modern epidemiology. In highly industrialized countries, this cancer is the second leading cause of death.

The risk of lung cancer is related to the duration and intensity of smoking cigarettes. Smoking a pack of cigarettes a day for 30 years increases the risk of lung cancer by 20 to 60 times in men, and 14 to 20 times in women, compared to people who have never smoked. The fact that lung cancer does not occur only in smokers indicates a genetic predisposition to this disease. However, the genes that transmit the predisposition to this disease remain unclear. The pathogenesis of lung cancer is associated with exposure to various carcinogens from the work and environment. These include asbestos and silicate fibers, organic compounds such as chloral methyl ether, diesel fumes and air pollution, as well as metals such as chromium and nickel, arsenic and ionizing radiation. The observation in the 1970s that patients with lung cancer had low levels of vitamin A sparked strong interest in the potential role of diet in regulating the risk of lung cancer. Subsequent studies have suggested that antioxidants may reduce the risk of lung cancer by inhibiting DNA damage.

The signs and symptoms manifested by patients with lung cancer depend on the histology of the tumor, the extent of the loco-regional invasion, and the location, size, and number of distant metastases. Asymptomatic lesions are most often those that are detected accidentally by chest radiography or CT scan. The symptoms 
associated with the primary tumor differ in central and peripherally located primary lesions. Central tumors located in the bronchi cause central symptoms: persistent cough, shortness of breath or haemoptysis. Tumors that affect the walls of the chest usually produce severe radicular pain or burning pain, with or without pleural effusion.

The current system for determining the stage of lung cancer is based on the revised tumor, nodule and metastasis (TNM) criteria. A detailed history and physical examination remain the most important step in the initial assessment of a patient with possible lung cancer. As part of a complete diagnosis of lung cancer, in addition to history and clinical examination, imaging methods and invasive non-surgical or surgical examinations are included. The basic diagnostic procedure is X-ray of the lungs in two projections, posteroanterior and lateral-lateral imaging, computed tomography (CT), positron emission tomography with fluorodeoxyglucose, Immunohistochemistry, magnetic resonance imaging and ultrasound.

The choice of treatment for lung cancer depends on the location and type of cancer. Surgery is the best chance of curing patients with resectable NSCLC. If surgery is not possible in some patients with resectable cancer (usually intranasal contraindications), radiotherapy is used to control the primary tumor and regional lymph nodes. Chemotherapy is the primary treatment for SCC. [1-7]

\section{Material and methods}

For the purposes of this research is used analytical-descriptive method of work for processing data for the number of diagnosed patients with lung cancer in the period from 2016-2019 in the municipality of Stip, Republic of North Macedonia.

The data for the patients are obtained from the Center for public health - Stip, North Macedonia.

\section{Result and Discussion}

ICD-10

C34 - malignant neoplasm of bronchus and lungs

- C34.0 - malignant neoplasm of the main bronchus

- C34.1 - malignant neoplasm of the upper lobe, bronchus or lungs

C34.2 - malignant neoplasm of the middle lobe, bronchus or lungs

C34.3 - malignant neoplasm of the lower lobe, bronchus or lungs

- C34.8 - a malignant neoplasm that crosses the edges of the bronchi and lungs

C34.9 - malignant neoplasm of indeterminate part of bronchus or lungs

Table 1. Malignant lung neoplasm in 2016 in Shtip

\begin{tabular}{|c|c|c|c|c|c|c|c|c|c|c|c|c|}
\hline \multirow{2}{*}{$\begin{array}{l}\text { ICD- } \\
10\end{array}$} & \multirow[b]{2}{*}{ Gender } & \multicolumn{11}{|c|}{ AGE } \\
\hline & & $\begin{array}{l}<1 \\
\Gamma\end{array}$ & $y^{1-6}$ & $\begin{array}{l}\text { 7- } 19 \\
y\end{array}$ & $\begin{array}{l}20- \\
24 y\end{array}$ & $\begin{array}{l}25- \\
29 y\end{array}$ & $\begin{array}{l}30- \\
34 y\end{array}$ & $\begin{array}{l}35- \\
44 y\end{array}$ & $\begin{array}{l}45- \\
54 y\end{array}$ & $\begin{array}{l}55- \\
64 y\end{array}$ & $\begin{array}{l}65- \\
74 y\end{array}$ & $\begin{array}{l}>75 \\
y\end{array}$ \\
\hline \multirow[t]{2}{*}{ C34.0 } & $\mathrm{M}$ & 0 & 0 & 0 & 0 & 0 & 0 & 0 & 0 & 1 & 0 & 0 \\
\hline & $\mathrm{W}$ & 0 & 0 & 0 & 0 & 0 & 0 & 0 & 0 & 0 & 0 & 0 \\
\hline \multirow[t]{2}{*}{ C34.1 } & $\mathrm{M}$ & 0 & 0 & 0 & 0 & 0 & 0 & 0 & 0 & 0 & 0 & 0 \\
\hline & $\mathrm{W}$ & 0 & 0 & 0 & 0 & 0 & 0 & 0 & 0 & 1 & 0 & 0 \\
\hline \multirow[t]{2}{*}{ C34.3 } & $\mathrm{M}$ & 0 & 0 & 0 & 0 & 0 & 1 & 0 & 0 & 1 & 0 & 0 \\
\hline & $\mathrm{W}$ & 0 & 0 & 0 & 0 & 0 & 0 & 0 & 0 & 0 & 0 & 0 \\
\hline \multirow[t]{2}{*}{ C34.8 } & $\mathrm{M}$ & 0 & 0 & 0 & 0 & 0 & 0 & 0 & 1 & 1 & 0 & 0 \\
\hline & $\mathrm{W}$ & 0 & 0 & 0 & 0 & 0 & 0 & 0 & 0 & 0 & 0 & 0 \\
\hline \multirow[t]{2}{*}{ C34.9 } & $\mathrm{M}$ & 0 & 0 & 0 & 0 & 0 & 0 & 0 & 3 & 5 & 5 & 0 \\
\hline & $\mathrm{W}$ & 0 & 0 & 0 & 1 & 0 & 0 & 0 & 3 & 0 & 1 & 1 \\
\hline
\end{tabular}




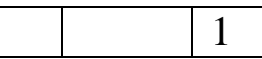

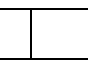

7

9

6

Table 2. Malignant lung neoplasm in 2017 in Shtip

\begin{tabular}{|c|c|c|c|c|c|c|c|c|c|c|c|c|}
\hline \multirow[t]{2}{*}{ ICD-10 } & \multirow[b]{2}{*}{ Gender } & \multicolumn{11}{|c|}{ Age } \\
\hline & & $\begin{array}{l}<1 \\
\mathrm{y}\end{array}$ & $y^{1-6}$ & $\begin{array}{l}\text { 7- } 19 \\
\mathrm{y}\end{array}$ & $\begin{array}{l}20- \\
24 y\end{array}$ & $\begin{array}{l}25- \\
29 y\end{array}$ & $\begin{array}{l}30- \\
34 y\end{array}$ & $\begin{array}{l}35- \\
44 y\end{array}$ & $\begin{array}{l}45- \\
54 y\end{array}$ & $\begin{array}{l}55- \\
64 y\end{array}$ & $\begin{array}{l}65- \\
74 y\end{array}$ & $\begin{array}{l}>75 \\
y\end{array}$ \\
\hline \multirow{2}{*}{ C34.0 } & $\mathrm{M}$ & 0 & 0 & 0 & 0 & 0 & 0 & 1 & 0 & 0 & 1 & 0 \\
\hline & W & 0 & 0 & 0 & 0 & 0 & 0 & 0 & 1 & 0 & 0 & 0 \\
\hline \multirow{2}{*}{ C34.1 } & $\mathrm{M}$ & 0 & 0 & 0 & 0 & 0 & 0 & 0 & 0 & 1 & 0 & 0 \\
\hline & $\mathrm{W}$ & 0 & 0 & 0 & 0 & 0 & 0 & 0 & 0 & 1 & 0 & 0 \\
\hline \multirow[t]{2}{*}{ C34.9 } & $\mathrm{M}$ & 0 & 0 & 0 & 1 & 0 & 0 & 2 & 5 & 10 & 9 & 0 \\
\hline & W & 0 & 0 & 0 & 0 & 0 & 0 & 0 & 1 & 1 & 0 & 1 \\
\hline TOTAL & 35 & & & & 1 & & & 3 & 7 & 13 & 10 & 1 \\
\hline
\end{tabular}

Table 3. Malignant lung neoplasm in 2018 in Shtip

\begin{tabular}{|c|c|c|c|c|c|c|c|c|c|c|c|c|}
\hline \multirow[t]{2}{*}{ ICD-10 } & \multirow[b]{2}{*}{ Gender } & \multicolumn{11}{|c|}{ Age } \\
\hline & & $\begin{array}{l}<1 \\
\mathrm{y}\end{array}$ & $\begin{array}{r}1- \\
6 y\end{array}$ & $\begin{array}{l}7- \\
19 y\end{array}$ & $\begin{array}{l}20- \\
24 y\end{array}$ & $\begin{array}{l}25- \\
29 y\end{array}$ & $\begin{array}{l}30- \\
34 y\end{array}$ & $\begin{array}{l}35- \\
44 y\end{array}$ & $\begin{array}{l}45- \\
54 y\end{array}$ & $\begin{array}{l}55- \\
64 y\end{array}$ & $\begin{array}{l}65- \\
74 y\end{array}$ & $\begin{array}{l}>75 \\
y\end{array}$ \\
\hline \multirow[t]{2}{*}{ C34.0 } & $\bar{M}$ & 0 & 0 & 0 & 0 & 0 & 0 & 0 & 0 & 1 & 0 & 0 \\
\hline & $\bar{W}$ & 0 & 0 & 0 & 0 & 0 & 0 & 0 & 0 & 0 & 0 & 0 \\
\hline \multirow[t]{2}{*}{ C34.1 } & $\mathrm{M}$ & 0 & 0 & 0 & 0 & 0 & 0 & 0 & 0 & 1 & 0 & 0 \\
\hline & $\mathrm{W}$ & 0 & 0 & 0 & 0 & 0 & 0 & 0 & 0 & 0 & 0 & 0 \\
\hline \multirow[t]{2}{*}{ C34.3 } & $\mathrm{M}$ & 0 & 0 & 0 & 0 & 0 & 0 & 0 & 1 & 0 & 0 & 0 \\
\hline & $\mathrm{W}$ & 0 & 0 & 0 & 0 & 0 & 0 & 0 & 0 & 1 & 0 & 0 \\
\hline \multirow[t]{2}{*}{ C34.8 } & $\mathrm{M}$ & 0 & 0 & 0 & 0 & 0 & 0 & 0 & 1 & 0 & 0 & 0 \\
\hline & $\mathrm{W}$ & 0 & 0 & 0 & 0 & 0 & 0 & 0 & 0 & 0 & 0 & 0 \\
\hline \multirow[t]{2}{*}{ C34.9 } & $\mathrm{M}$ & 0 & 0 & 0 & 0 & 0 & 0 & 0 & 1 & 5 & 4 & 0 \\
\hline & $\mathrm{W}$ & 0 & 0 & 0 & 1 & 0 & 0 & 0 & 2 & 1 & 3 & 0 \\
\hline TOTAL & 22 & & & & 1 & & & & 5 & 9 & 7 & \\
\hline
\end{tabular}

Table 4. Malignant lung neoplasm in 2019 in Shtip

\begin{tabular}{|c|c|c|c|c|c|c|c|c|c|c|c|c|}
\hline \multirow[t]{2}{*}{ ICD-10 } & \multirow[t]{2}{*}{ Gender } & \multicolumn{11}{|c|}{ Age } \\
\hline & & $<1 y$ & $\begin{array}{c}1- \\
6 y\end{array}$ & \begin{tabular}{|l|}
$7-$ \\
$19 y$
\end{tabular} & $\begin{array}{l}20- \\
24 y\end{array}$ & $\begin{array}{l}25- \\
29 y\end{array}$ & $\begin{array}{l}30- \\
34 y\end{array}$ & $\begin{array}{l}35- \\
44 y\end{array}$ & $\begin{array}{l}45- \\
54 y\end{array}$ & $\begin{array}{l}55- \\
64 y\end{array}$ & $\begin{array}{l}65- \\
74 y\end{array}$ & $>75 y$ \\
\hline \multirow[t]{2}{*}{ C34.1 } & $\mathrm{M}$ & 0 & 0 & 0 & 0 & 0 & 0 & 0 & 0 & 0 & 1 & 0 \\
\hline & Ж & 0 & 0 & 0 & 0 & 0 & 0 & 0 & 0 & 0 & 0 & 0 \\
\hline \multirow[t]{2}{*}{ C34.9 } & $\mathrm{M}$ & 0 & 0 & 0 & 0 & 0 & 0 & 0 & 3 & 1 & 3 & 0 \\
\hline & Ж & 0 & 0 & 0 & 0 & 0 & 0 & 0 & 0 & 0 & 0 & 0 \\
\hline TOTAL & 7 & & & & & & & & 3 & 1 & 3 & \\
\hline
\end{tabular}

All the statistical data taken from the Center for public health - Shtip for the number of patients with lung cancer are presented with the tables above. The processed data show that lung cancer is more common in men and occurs more often at the age of 55-65 years, while in women there is no dominance of a certain age group.

- The obtained data shows that the total number of newly registered cases of lung cancer in Shtip for 2016 is a total of 25 of which 18 of the patients are men, most of them are aged 55 to 65 years, and 7 of the patients are women, the largest number of patients are aged 45 to 54 years. 
- The obtained data shows that the total number of newly registered cases of lung cancer in Shtip for 2017 is a total of 35 of which 30 of the patients are men, most of them are aged 55 to 65 years, and 5 of the patients are women, the largest number of patients are aged 45 to 64 years.

- The obtained data shows that the total number of newly registered cases of lung cancer in Shtip for 2018 is a total of 22 of which 14 of the patients are men, most of them are aged 55 to 65 years, and 8 of the patients are women, the largest number of patients are aged 65 to 74 years.

- The obtained data shows that the total number of newly registered cases of lung cancer in Shtip for 2019 is a total of 7 of which are all registered in men, most of them are aged 45 to 54 and 65 to 75 years, in 2019 there are no registered case of lung cancer in women in Stip.

According to the tables shown and the discussion above, it is noted that lung cancer is a very common malignancy in most cases diagnosed as C34.9- malignant neoplasm of an unspecified part of the bronchus or lungs. White cancers are most commonly diagnosed in men aged 55 to 64 but no age or gender is spared, and can occur even in young people aged 20 to 24 . Due to the frequency of this cancer, it is important to raise the awareness of the population to prevent or detect the disease early, which improves the chances for a better prognosis and a better outcome of treatment.

\section{Conclusion}

In the Republic of N. Macedonia, malignant neoplasms due to high mortality are in the second place in the structure of causes of death, immediately after cardiovascular diseases. It is most often diagnosed in men in the fifth and sixth decades of life, while in women the number is much lower than in men. Although the incidence of lung cancer is very high, in 2019 in the municipality of Shtip there is a significant decrease in the number of diagnosis. The purpose of early detection of cancer is to reduce mortality, ie longer survival of the patients. If the treatment is started on time, life expectancy is significantly extended.

\section{Source of funding}

This research received no specific grant from any funding agency in the public, commercial, or not-forprofit sectors.

\section{Conflict of interest}

The author have declared that no competing interests exist.

\section{Acknowledgement}

None.

\section{Statement of Informed Consent}

Written informed consent was obtained from the patient for their anonymized information to be published in this article.

\section{References}

[1] Arko D et al. Onkologija : ucebnik za studente medicine, 1 izdanje Onkoloski institut Ljubljana 2018

[2] Chabner AB, Longo LD; Harrisons's manual of oncology, $2^{\text {nd }}$ edition McGraw-Hill Eduction 2014

[3] Niederhuber EJ et al.; Abeloff's Clinical Oncology, $6^{\text {th }}$ edition, Elsevier 2020

[4] Pass IH et al.; Thoracic oncology, $2^{\text {nd }}$ edition, Elsevier 2018

[5] Simonovska Lj; Selected Chapters in Pulmonology and Physiology - Goce Delchev University, Faculty of Medical Sciences, 2015

[6] Smichkoska S; Special oncology, authorized lectures, University "St. Cyril and Methodius "Faculty of Medicine - Skopje, 2014

[7] Shumanov G, Zisovska E; Anatomy - Goce Delchev University, Faculty of Medical Sciences, 2012 